\title{
RELATIONSHIP BETWEEN INVENTORY MANAGEMENT AND INDUSTRIES BECOMING SICK, ESPECIALLY IN THIRD WORLD COUNTRIES
}

\author{
A. K. M. Solayman Hoque ${ }^{1}$, S.K. Biswas ${ }^{2}$ and M. A.Wazed ${ }^{3}$ \\ ${ }^{1}$ Bangladesh Steel \& Engineering Corporation, Dhaka, Bangladesh \\ ${ }^{2}$ Department of Mech. \& Production Eng., Ahsanullah University of Sc. \& Tech.(AUST), Bangladesh \\ ${ }^{3}$ Department of Mech. Eng., Chittagong University of Eng. \& Tech.(CUET), Bangladesh \\ Corresponding e-mail: solaymanhoq@gmail.com
}

\begin{abstract}
This article finds the relationship of Inventory management with industries becoming sick. Inventory planning and control are of special importance to sales, production, and finance of any firm. Proper inventory management gives an idea of relationship between raw material, work-in-process and finished goods or consumption of finished goods. From the collected data it is clear that many local plants have either no fixed norm(s) or do not practice proper way of controlling the inventory. This might be the case in many third world countries. In this article it has been discussed how to overcome sickness of industries by controlling and standardizing inventory planning and control. Also how productivity and firm's financial conditions are affected by proper inventory management has also been discussed in this article.
\end{abstract}

Keywords: Inventory planning and control, various inventory planning \& control tools, production planning and control, financial analysis, sick industries, productivity analysis and improvement, third world countries.

\section{INTRODUCTION ${ }^{1-4,11}$}

It is clearly known that inventories have a direct impact upon the firms' profit and proper inventory management is a major contributing factor to fluctuations in business activity. Thus both from operational and profitability point of view, maintaining an optimum level of inventory is very important for any business enterprise.

Also inventory planning and control is of special importance to each of the functional areas in the organizations like sales, production and finance. The vital aspect of inventory planning is to find out and maintain the optimum level of inventory in an enterprise and inventory control is not only the control of physical goods owned by an enterprise but also the control of the amount of funds invested in inventories of each type.

Thus inventory management can be considered as a strategic factor in any organization since we know that inventory position and profitability are directly related.

\section{INVENTORY MANAGEMENT ${ }^{2,11}$}

Efficient inventory management is maintaining the constant flow of units into and out of an existing inventory. The process involves controlling the level of units in stock in order to prevent the inventory from becoming too high and good inventory management also controls the costs associated with the inventory, both from the perspective of the total value of the goods included and the tax burden generated by the cumulative value of the inventory.
Inventory management is not limited to documenting the delivery of raw materials and the movement of those materials into operational process. The movement of those materials as they go through the various stages of the operation is also important. Inventory management has to do with keeping accurate records of finished goods that are ready for shipment. This often means posting the production of newly completed goods to the inventory totals as well as subtracting the most recent shipments of finished goods to buyers.

Inventory management is one of the financial control areas for minimizing cost of production. The aim of the inventory management should be to avoid excessive and at the same time keeping adequate levels of inventories and maintain sufficient inventory for smooth production and sales operations.

The main objectives of inventory management are as follows ${ }^{8}$ :

(i) To ensure that the supply of raw material and finished goods will remain continuous so that production process is not halted and demands of customers are duly met.

(ii) To minimize carrying cost of inventory,

(iii) To keep investment in inventory at optimum level,

(iv) To reduce the losses against deterioration, obsolescence and wastage etc.,

(v) To make arrangement for sale of slow moving items, and

(vi) To minimize inventory ordering costs, etc. 
Inventory management ${ }^{5,11}$ includes the following:

1. Inventory planning,

2. Financing inventory,

3. Inventory control.

\section{Inventory Planning ${ }^{9}$}

Inventory planning is the method and procedures the company uses to determine the amount of products they should have on hand for meeting consumer demand. This planning may involve several steps, depending on the company's inventory management system and business operations. The first step of inventory planning is to estimate future sales. This estimation can be conducted by reviewing historical sales records to ascertain various sales trends for company products. The next step in inventory planning is to purchase the necessary products for business locations. This process includes selecting the products, type of the displays, receiving or verification methods and reorder system.

The major goal of inventory planning is to find out and maintain the optimum level of inventory. The capital investment in inventories is of major importance in all manufacturing enterprises. In summary we can say that the objective of inventory planning is to maintain inventories so as to keep inventory costs in the lowest range of investment, sufficient to meet the production, sales, and financial requirements of an enterprise

\section{Financing inventory}

Finance is the administrative function(functions) in an organization which has (have) to be done by the management along with the flow of cash so that the organization will have the means to carry out its objectives satisfactorily and at the same time meet its obligations as they become due.

\section{Inventory control ${ }^{5}$}

Inventory control is concerned with minimizing total cost of inventory. This requires that each step in inventory process is required to be checked with established standards and where deviations occur, actions should be taken immediately. Inventory control includes control of physical goods and of the amount of fund invested in inventories. Some of the more common $\operatorname{areas}^{[11]}$ in which inventory control can be applied are:
i. Raw materials availability,
ii. Finished goods availability,
iii. Work in process,
iv. Reorder point,
v. Bottleneck enhancement,
vi. Outsourcing.

\section{CASE STUDY ${ }^{6-7}$}

The enterprise $\mathbf{A}$ where the case study was made is one of the public sector enterprises of Bangladesh. The commercial production in the plant was started on August, 1980. It is one of the heavy industries established by the Government of Bangladesh with the objective of producing equipment in electrical supply line. The products of the plant include distribution transformer of different capacities, lightning arrestor, drop-out fuses, power transformer etc. At present they are manufacturing only distribution transformer of capacities $100 \mathrm{KVA}, 200 \mathrm{KVA}$ and $250 \mathrm{KVA}$. The plant also takes repair works of transformers from different government organizations. In the following inventory management policies of the company are discussed.

\section{Inventory Planning in A}

The relevant aspects, which have been used later, for inventory planning of the company, are discussed below:

\section{Lead time}

Lead time is a key consideration in inventory planning. It means the time between placement of order and receiving of material. So it is important to the plant management that in order to reduce lead time it is necessary to complete procurement formalities as quickly as possible.

\section{Economic Order quantity (EOQ)}

Determination of the EOQ for ordering is also most important to the management of the plant. EOQ or economic lot size is that level of inventory which minimizes the total cost associated with the inventory management. Records of EOQ for the company under consideration are shown in Table 4. Table 3 shows the inventory position of company $\mathbf{A}$. The plant which does not follow the economic order quantity for selecting the size for order placement pays high total cost or in a word we can say the company pays high inventory carrying cost and high ordering cost ultimately.

\section{Inventory Purchase policy:}

The level of inventory is closely related to inventory purchase policy. The procurement records of the company $\mathbf{A}$, under case study, are shown in Table 1 and in Table 2 below. The raw materials and production components should be so planned that they are available at the right time, because delays, in procurement caused by lack of proper planning can held up production temporarily. The basic objective of the purchasing function is to ensure continuity of supply and of maintaining the lowest cost of finished goods. 
Table 1. Procurement of some important Raw Materials of Company A for the FY $2011-2012^{6}$

\begin{tabular}{|l|c|c|c|c|c|}
\hline \multicolumn{1}{|c|}{$\begin{array}{c}\text { Description of } \\
\text { raw material }\end{array}$} & $\begin{array}{c}\text { Annual } \\
\text { Requirement } \\
\text { of material }\end{array}$ & $\begin{array}{c}\text { Cost per unit of } \\
\text { Material } \\
\text { ( Taka })\end{array}$ & $\begin{array}{c}\text { Total cost } \\
\text { (Taka in Lac) }\end{array}$ & $\begin{array}{c}\text { Cost per Order } \\
\text { ( Taka })\end{array}$ & $\begin{array}{c}\text { Carrying cost in } \\
\text { Taka } \\
\text { ( Per ton })\end{array}$ \\
\hline $\begin{array}{l}\text { Silicon Electrical } \\
\text { Steel Sheet }\end{array}$ & $360 \mathrm{MT}$ & 210210 & 756.75 & 790 & 60 \\
\hline $\begin{array}{l}\text { Paper Insulated } \\
\text { Copper Strip }\end{array}$ & $44 \mathrm{MT}$ & 846925 & 373.52 & 700 & 2000 \\
\hline $\begin{array}{l}\text { Super Enamel } \\
\text { Copper Wire }\end{array}$ & $60 \mathrm{MT}$ & 765628 & 472.58 & 600 & 1000 \\
\hline M.S. Sheet & $130 \mathrm{MT}$ & 85 & 110.50 & 100 & 40 \\
\hline Transformer oil & $2548 \mathrm{drum}$ & 21431 & 546.06 & 400 & 50 \\
\hline
\end{tabular}

Table 2. Procurement of some important Raw Materials of Company A for the FY $2012-2013^{6}$

\begin{tabular}{|l|c|c|c|c|c|}
\hline $\begin{array}{c}\text { Description of } \\
\text { raw material }\end{array}$ & $\begin{array}{c}\text { Annual } \\
\text { Requirement } \\
\text { of material }\end{array}$ & $\begin{array}{c}\text { Cost per unit of } \\
\text { Material } \\
\text { ( Taka })\end{array}$ & $\begin{array}{c}\text { Total cost } \\
\text { (Taka in Lac) }\end{array}$ & $\begin{array}{c}\text { Cost per Order } \\
\text { ( Taka) }\end{array}$ & $\begin{array}{c}\text { Carrying cost in } \\
\text { Taka } \\
\text { ( Per ton) }\end{array}$ \\
\hline $\begin{array}{l}\text { Silicon Electrical } \\
\text { Steel Sheet }\end{array}$ & $260 \mathrm{MT}$ & 270140 & 701.50 & 790 & 80 \\
\hline $\begin{array}{l}\text { Paper Insulated } \\
\text { Copper Strip }\end{array}$ & $54 \mathrm{MT}$ & 795907 & 429.79 & 1000 & 2000 \\
\hline $\begin{array}{l}\text { Super Enamel } \\
\text { Copper Wire }\end{array}$ & $68 \mathrm{MT}$ & 808788 & 554.02 & 700 & 1000 \\
\hline MS Sheet & $130 \mathrm{MT}$ & 85 & 110.50 & 100 & 40 \\
\hline Transformer oil & $113 \mathrm{Drum}$ & 29534 & 334.64 & 400 & 50 \\
\hline
\end{tabular}

\section{Inventory Profile ${ }^{1}$}

The major components of inventory of the company under case study are raw materials, work in process, finished goods, stores and spares and goods in transit. The size of inventory is estimated on the basis of previous records and production targets. In estimating the size of inventory the factors which have usually been considered by this company are rate of consumption, available source of raw materials and production target.

\section{Inventory Control ${ }^{2,11}$}

Inventory control is a set of policies and operating procedures that are designed to maximize company's use of inventory so as to generate the maximum profit. Thus it is designed to maximize company's use of inventory investment without affecting customer satisfaction levels. It is also essential for effective production and financial control. Proper inventory control will reduce costs arising from the faults in planning execution or in other inventory functions. There are three methods of controlling the Inventory such as (i) physical control,(ii) stock verification, and (iii) budgetary control.

\section{Physical Control ${ }^{1}$}

It is one of the most important functions in the inventory management. For physical control of stores, it is essential that material of correct quantity is available as and when required with due attention to costs and difficulties for storage. One of the basic methods of controlling stock by quantity is level control. There are various kinds of stock levels but fundamental among them are maximum, minimum and ordering levels.

\section{Maximum Level}

This is the level beyond which stock should not go overstocking and thereby using working capital in a proper way. 


\section{Minimum Level}

This is the level below which the stock of an item should not fall. This can be considered as safety stock or buffer stock.

\section{Reorder Level}

This is the point fixed between maximum and minimum stock level at which it is necessary to initiate purchase requisitions for fresh supplies.

Table 3. Closing inventory position of fiscal years 2007-2008 to 2012-2013 of the Company $\mathrm{A}^{6}$

(Figures in Lac)

\begin{tabular}{|c|c|c|c|c|c|c|c|}
\hline $\begin{array}{c}\text { Financial } \\
\text { year }\end{array}$ & $\begin{array}{l}\text { Stock of } \\
\text { raw } \\
\text { materials } \\
\text { ( Taka ) }\end{array}$ & $\begin{array}{l}\text { Work in } \\
\text { Process } \\
\text { ( Taka) }\end{array}$ & $\begin{array}{c}\text { Finished } \\
\text { Goods } \\
\text { ( Taka ) }\end{array}$ & $\begin{array}{l}\text { Stores \& } \\
\text { Spares } \\
\text { ( Taka ) }\end{array}$ & $\begin{array}{l}\text { Stores in } \\
\text { Transit } \\
\text { ( Taka ) }\end{array}$ & $\begin{array}{l}\text { Customs for } \\
\text { bonded } \\
\text { Goods } \\
\text { ( Taka ) }\end{array}$ & $\begin{array}{l}\text { Total } \\
\text { Inventory } \\
\quad \text { (Without } \\
\text { bonded goods) } \\
\quad \text { ( Taka ) }\end{array}$ \\
\hline 2007-08 & 205.09 & 490.50 & $\begin{array}{l}1001.82 \\
*(37.61)\end{array}$ & 163.43 & 702.37 & 285.24 & 2663.21 \\
\hline $2008-09$ & 169.84 & 375.40 & $\begin{array}{l}1295.15 \\
*(35.56) \\
\end{array}$ & 163.76 & 1637.21 & 630.75 & 3641.36 \\
\hline $2009-10$ & 395.70 & 853.18 & $\begin{array}{l}1496.04 \\
*(38.04)\end{array}$ & 151.85 & 1036.66 & 557.54 & 3933.43 \\
\hline 2010-11 & 393.59 & 694.29 & $\begin{array}{l}2198.78 \\
*(51.43)\end{array}$ & 161.20 & 826.33 & 421.15 & 4274.69 \\
\hline 2011-12 & 420.30 & 405.36 & $\begin{array}{l}2386.59 \\
*(65.87)\end{array}$ & 172.26 & 238.15 & 398.39 & 3622.66 \\
\hline $2012-13$ & 210.38 & 570.75 & $\begin{array}{l}2133.10 \\
*(51.58)\end{array}$ & 160.98 & 1057.52 & 481.84 & 4132.73 \\
\hline
\end{tabular}

*Star mark (in bracket) indicates percentage of total inventory

This Table shows that there were huge build up finished goods inventory in Company A during the period 201011,'11-12 and in '12-'13. It was also evident from above Table that during the said periods the finished goods inventory was above $50 \%$ of the total inventory (Table 3).We think, this might have affected the inventory turnover ratio of the Company. In the Table 4 as shown below, EOQs as determined by the company for the purchase of raw materials are shown.
Sample percentage Calculation (as shown in Column 4)

$$
=\frac{2386.59}{3622.66} \times 100 \%=65.87 \%
$$

Total Inventory $=$ Summation of all columns except that in_bonded goods (Column 7). Bonded goods usually were kept in the customs go-down, and not in hand of the company as inventory. For this reason it is not added or considered in the total.

Table 4. Economic Order Quantity Status of two financial years ${ }^{6.7}$

\begin{tabular}{|l|c|c|c|c|}
\hline \multicolumn{1}{|c|}{ Description of Materials } & FY 2011-2012 & \multicolumn{2}{|c|}{ FY 2012-2013 } \\
\cline { 2 - 5 } & $\begin{array}{c}\text { Estimated } \\
\text { Annual } \\
\text { Requirement }\end{array}$ & $\begin{array}{c}\text { Economic Order } \\
\text { Quantity } \\
\text { (EOQ) }\end{array}$ & $\begin{array}{c}\text { Estimated } \\
\text { Annual } \\
\text { Requirement }\end{array}$ & $\begin{array}{c}\text { Economic Order } \\
\text { Quantity } \\
\text { (EOQ) }\end{array}$ \\
\hline Silicon Electrical Steel Sheet & $360 \mathrm{MT}$ & $168 \mathrm{MT}$ & $260 \mathrm{MT}$ & $135 \mathrm{MT}$ \\
\hline Paper Insulated Copper Strip & $44 \mathrm{MT}$ & $27 \mathrm{MT}$ & $54 \mathrm{MT}$ & $30 \mathrm{MT}$ \\
\hline Super Enamel Copper Wire & $60 \mathrm{MT}$ & $36 \mathrm{MT}$ & $68 \mathrm{MT}$ & $36 \mathrm{MT}$ \\
\hline M.S. Sheet 2.5 mm & $130 \mathrm{MT}$ & $73 \mathrm{MT}$ & $130 \mathrm{MT}$ & $68 \mathrm{MT}$ \\
\hline Transformer Oil & 2548 Drum & $131 \mathrm{Drum}$ & 1134 Drum & 121 Drum \\
\hline
\end{tabular}




\section{Stock verification}

Stock verification is a process of physical counting, measuring or weighing the entire range of items in the stores and recording the results in a systematic manner. The physical inventory is usually taken periodically or continuously in A.

\section{$\mathrm{ABC}$ analysis}

It is done by counting values and numbers of items to classify inventory. In such classification, inventories are classified into A, B and C groups according to value. A contains the higher value items, $\mathrm{B}$ is medium cost and $\mathrm{C}$ is low value items. Controlling is applied such that relatively more control for $\mathrm{A}$ and relatively least control for $\mathrm{C}$ items. This technique of stock control is also known as stock control according to value and importance.

\section{Perpetual inventory system}

This system maintains a detailed daily inventory record throughout the period for each item stocked. Under this system, inventory recording includes opening inventory, purchases, issues for production, and a continuous balance of inventory. The management of the company under case study used to control its inventory through perpetual inventory system and through annual physical inventory stock verification system. Actually the management used to take the stock and prepare inventory sheet at the end of every year for accounting purpose.

\section{Budgetary Control}

Budget is an estimate. Budgetary control involves the preparation and controlling of estimates for all phases of the business like production, sales, expenses, financing etc. Budgetary control involves setting of standards, comparison between the actual and standards and taking corrective actions if needed. The company prepares production, sales and inventory budget on the basis of production target. It appears that sometimes budgets are not properly followed so budgetary control is needed to be done.

\section{Inventory Turnover ratio}

The inventory turnover ratio is based on the relationship between sales and closing inventory. The turnover ratio is computed by dividing the cost of goods sold by the average inventory the company holds. Table 5 shows the inventory turnover ratios of the company under case study.

It is known that the higher the inventory turnover ratio the greater is the volume of the business. The lower the turnover the higher is the risk of loss through price decline and the changes in demand.

Table 5. Inventory Turnover Ratio of several years of the Company A under case study ${ }^{6}$

(Figures in crores )

\begin{tabular}{|c|c|c|c|c|c|}
\hline Financial Year & $\begin{array}{c}\text { Opening } \\
\text { Inventory }\end{array}$ & $\begin{array}{c}\text { Closing } \\
\text { Inventory }\end{array}$ & $\begin{array}{c}\text { Average } \\
\text { Inventory }\end{array}$ & $\begin{array}{c}\text { Cost of Goods } \\
\text { Sold }\end{array}$ & Turnover Ratio \\
\hline $2006-07$ & 24.63 & 24.35 & 24.49 & 33.97 & 1.38 \\
\hline $2007-08$ & 24.35 & 29.48 & 26.92 & 22.63 & 0.84 \\
\hline $2008-09$ & 29.48 & 42.72 & 36.10 & 40.82 & 1.13 \\
\hline $2009-10$ & 42.72 & 44.90 & 43.81 & 49.32 & 1.13 \\
\hline $2010-11$ & 44.90 & 46.95 & 45.93 & 47.85 & 1.04 \\
\hline $2011-12$ & 46.95 & 40.21 & 43.58 & 40.75 & 0.94 \\
\hline $2012-13$ & 40.21 & 46.16 & 43.18 & 37.39 & 0.86 \\
\hline
\end{tabular}

Table 6. Performance of the company $\mathrm{A}^{6,7}$

\begin{tabular}{|l|c|c|c|c|c|c|}
\hline & $2007-08$ & $2008-09$ & $2009-10$ & $2010-11$ & $2011-12$ & $2012-13$ \\
\hline Production & 28.95 & 45.25 & 51.34 & 54.98 & 42.63 & 34.76 \\
\hline Sales & 23.99 & 45.88 & 56.85 & 59.51 & 45.78 & 39.77 \\
\hline Profit/ (Loss) & $(5.99)$ & $(3.96)$ & $(2.88)$ & $(2.79)$ & $(7.95)$ & $(9.75)$ \\
\hline
\end{tabular}

From Table 5, it was seen that the turnover ratio of the company under study periods are 1.38 in 2006-07, 0.84 in $2007-08,1.13$ in $2008-09,1.13$ in $2009-10,1.04$ in $2010-11,0.94$ in 2011-12, 0.86 in 2012-13. Our physical verification shows a downward trend on average in inventory turnover. This might have adversely affected the profitability of the plant as shown in Table 6. BEP (Annexure 1) of the company in 200708 was found to be 1033 unit, amounting to Taka. 49.06 crores, whereas sales was 23.99 crores (from Table 6) 
which was less than the BEP. Similarly, in 2011-12, BEP was 1147 unit amounting to Taka. 64.03 crores, whereas sales was 45.78 (from Table 6) crores which is less than the BEP. In 2009-10 and 2010-11, we found that the sales was higher than the production cost, it might be due to the sales including previous year's stock of finished goods.

\section{FINDINGS}

It was evident that proper inventory management is essential for effective production and financial control. It was seen from the Table 3 that in FY 2010-11, FY 2011-12, FY 2012-13 finished goods became more than $50 \%$ of the total inventory. As a result, the performance of the company was not satisfactory i.e., the losses of the company increased ultimately.

Due to over stock of inventory, working capital of the company was blocked and as a result the company could not procure raw material in time. It affected the productivity of the company ultimately. We came to know the fact that the enterprise received $50 \%$ amount from the client as advance against each purchase order. So, the company could not pull its normal activities; even they could not give the salary and wages in time. Over stocking for one or two particular inventories like Transformer oil and Silicon steel sheet working capital was blocked for purchasing of other inventories like super enameled copper wire, insulated paper etc. So, capital was required at that time and the authorities could not procure goods in time. As a result production was hampered for a long time. After getting advance they took procurement action and at the same time gave salary and wages to the employees and labor force as they had no money in fund.

The following are the summary of findings from observations of actual data collected from the company A under case study:

(i) It was seen that proper inventory management system was not followed by the company. In estimating the size of inventory the company considered rate of consumption, production target, and available source of material. Sometimes the enterprise procured raw materials as per demand i.e. on the basis of purchase order. When the company generally receive a new purchase order from the client with advance, due to shortage of working capital. then the authority usually procure exact amount of required inventories or even few more so that they meet the customer demand in time.

(ii) The company did not follow the economic order quantity determination policy, It is clearly understood from the Table 4 that there is a big difference in quantity between estimated annual requirement and economic order quantity for example in case of transformer oil the estimated amount is 2548 drum (FY 2011-12) whereas the EOQ is only 131 drums only.

(iii) The company did not maintain proper stock level and for that reason unnecessary locking up of capital was observed. From Table $5 \& 6$ we found that in FY 2011-12 production was 42.63 crores whereas opening inventory was 46.95 crores; and that in FY 2012-13 production was 34.76 crores whereas opening inventory was 40.21 crores. Here, we can see that for FY 2011-12, opening inventory was higher than the production cost of that year i.e. we can conclude that proper inventory or EOQ was not maintained and advance procurement for the whole year was done and possibly due to that fact working capital was blocked.

(iv) In a word it can be said that the company have no fixed norm in order to control inventory. In FY 2011-12 from Table 4, we found that out of 2548 drum 1176 drum transformer oil had been purchased in a single order out of total 3 orders, as has been known from the purchase department of the company, whereas EOQ of that material was only $131 \mathrm{drum}$. This proves that excessive procurement was done and EOQ or any other inventory control was not done.

\section{CONCLUSION}

In general it can be inferred that the industrial scenario, in Bangladesh and probably in all $3^{\text {rd }}$ world countries, is characterized by high production cost and low productivity. We think for that reason the products of Govt. enterprises fail to compete in the market and hence industrial development, in the public sectors, is not gaining momentum. We also can conclude that the public sector enterprises have not yet been able to introduce proper inventory planning control devices. It is clear that in these modern days, the enterprises of public sector are not following scientific method of inventory management. They are still maintaining procurement order on the basis of purchase order, production target and available sources of material. Thus profit margin becomes lower, working capital wipes out and the industry gradually become sick. This might be due to lack of proper education and training so, proper training is necessary in applying inventory management. Here, we did not consider the uncertainties in supply and demand due to various causes like social, health and safety, economic and political reasons. Although, in this competitive business arena JIT, Lean Manufacturing, maintaining zero inventory, etc., are the cry of the day, and the authors believe these tools should be tried to follow, but we did 
not consider those in this article as the company has not been following them now.

\section{RECOMMENDATIONS}

We would like to mention some recommendations below from the findings:

(i) Every industry should maintain standardized and tested Inventory planning and control methods to reduce cost and increase profit margin,

(ii) Every Industry should use proper tools of inventory control like maintaining the level of inventory, economic order quantity, etc. and also should keep records of inventory properly on the basis of production target and present stock position, etc.

(iii) Also we are of the opinion that every manufacturing entity should keep close eye on
a) Shortage of fund,
b) Uncertainty of market,
c) State of foreign exchange,
d) Bank loan, etc.

(iv) Policy of clearing of finished goods should be pursued at any cost,

(v) Payment of bank loan should be made regularly at least by installment.

\section{REFERENCES}

1. Paul, NilimaRani, “ Inventory Planning \& Control:

A case study",Chittagong University Studies, Commerce Volume -5, 1989, p.143-158.

2. Hatten, Timothy, S; “ Management" , Houghton, Miffin Company, USA, p. 341-347.

3. Block, Stanley. B and Geoffrey A. Hirt; "Foundations of Financial Management", New York, Mc- Graw Hill Co, 2012, p. 209-213.

4. Khan, M.Y and Jain, P.K., " Financial Management" , Tata Mc-Graw Hill Publishing Co, New Delhi, ch-16, 1979.

5. Love, Stephen; “Inventory Control”, New York, USA.

6. Audit report of company(A), 2006, 2007, 20082013, etc.

7. MIS report of company (A), 2006, 2007, 20082013, etc.

8. Web site : http://www.answers.com

9. Web site : http:// www.wisegeek.com

10. Web site : www.accountingtools.com/inventory

11. Heizer, Jay and Render, Barry, "Production Operations Management ", 4th Edition, pp. 574-601. Prentice Hall International, Inc., USA.

\section{ANNEXURE 1}

\section{Calculation of Break -even point}

All relevant data were obtained from the company's marketing Department.

BEP $($ in unit $)=\frac{\text { Total Fixed Cost }}{\text { Unit Selling Price }- \text { Variable Cost }}$

\section{Calculation FY 2007-08}

Total Fixed Cost $=$ Tk. 158066000

Unit Selling Price $=$ Tk. 475000

Variable Cost $\quad=$ Tk. 321957

Hence, BEP $($ In Unit $)=\frac{158066000}{475000-321957}=1032.82$

$$
\approx 1033 \text { Unit }
$$

Total Cost $=$ Tk. 475000 per unit $\mathrm{x} 1033$ unit

$$
=\text { Tk.49.06 Crores }
$$

\section{Calculation for FY 2011-12}

$$
\begin{aligned}
& \text { Total Fixed Cost }=\text { Tk. } 225400000 \\
& \text { Unit Selling Price }=\text { Tk. } 558250 \\
& \text { Variable Cost }=\text { Tk. } 361657 \\
& \text { Hence, BEP (In Unit) }=\frac{225400000}{558250-361657}=1146.53 \\
& \approx 1147 \text { Unit } \\
& \text { Total Cost }=\text { Tk. } 558250 \text { per unit x } 1147 \text { unit } \\
&=\text { Tk.64.03 Crores }
\end{aligned}
$$

